\title{
Protein GR6
}

National Cancer Institute

\section{Source}

National Cancer Institute. Protein GR6. NCI Thesaurus. Code C29687.

Protein GR6 (149 aa, 16 kDa) is encoded by the human LINC01565 gene. This protein may play a role in the suppression of cell growth. 